\title{
Possessed by the Right Hand: The Problem of Slavery in Islamic Law and Muslim Cultures
}

\author{
Bernard K. Freamon \\ Leiden: Brill, 2019. 586 pages.
}

The last several years have seen an explosion of scholarly interest in slavery in the Islamic world and other global contexts. Recent contributions to this field include Jonathan A.C. Brown's Slavery in Islam and Mary Ann Fay's edited volume, Slavery in the Islamic World; a new edition of Orlando Patterson's seminal Slavery and Social Death has also recently been published with a new preface. 
With his ambitious and erudite monograph, Possessed by the Right Hand: The Problem of Slavery in Islamic Law and Muslim Cultures, Bernard K. Freamon intervenes in this field from the perspective of a legal scholar. His legal focus emerges most strongly in the final two chapters, in which he urges Muslims and scholars of Islam to confront the continued legacy of slavery in the contemporary Islamic world. This exhortation is embedded within a broadly transhistorical and transregional study of slavery in the Middle East and Indian Ocean, ranging from ancient Persia to $19^{\text {th }}$-century Zanzibar to contemporary Arabia. Most of this historical material is based on a synthesis of secondary scholarship, rather than a new analysis of primary sources.

To show the deep historical roots of slavery and the slave trade in Islamic world, Chapter 1 begins with an overview of slavery in the pre-Islamic Middle East. The chapter is impressively global in its scope; it does not simply focus on pre-Islamic Arabia and the Mediterranean, but also includes Mesopotamia, Persia, and India. To organize this wealth of material, Freamon focuses on the following themes: forms of slave labor, including "elite slaves" such as temple and palace slaves; the provenance of slaves, including both internal and external sources of slaves; and the relationship between imperialism and the slave trade.

While the first chapter shows that Islam emerged into a world filled with slavery, Chapter 2 argues that the Quran and Sunna had a strong "emancipatory ethic" (95) and a spirit of "pietistic egalitarianism" (105). This spiritual egalitarianism did not necessarily translate into juridical equality, but it created an ethical imperative to work towards social and material equality. The most original argument presented in this chapter is that the Quranic phrase mā malakat aymānukum ("possessed by the right hand") is not merely a euphemism for slave or concubine, but has connotations of honor, kindness, mutuality; the milk al-yamin deserves good treatment and basic human rights. Freamon never falls into the trap of arguing that Islamic slavery is therefore benign; rather, he ends the book by suggesting that "to be 'possessed by the right hand' is no longer a good thing" (516).

How can one explain the persistence of slavery and the slave trade in Islamic societies-or even more disturbingly, the 'ulama's persistent and explicit justifications of enslavement-if the Quran and Sunnah are so clearly egalitarian? In Chapters 3 and 5, Freamon points the finger at imperialism, with its ethos of domination and materialism. Chapter 3 contains a broad overview of the history of slavery and the slave trade in the premodern 
Islamic world; chapter 5 continues the theme of imperialism in the modern Islamic world. In these chapters, Freamon implies that whenever Islam and imperialism combine, the domineering ethos of imperialism will necessarily overtake and undermine the egalitarian ethos of Islam. This argument is intended as a criticism of jihadi-salafi groups such as ISIS, whose vision of Islam is sullied by imperialism. While I appreciate the point Freamon is making and share his underlying value of anti-imperialism, I suggest that he draws too sharp a line between the egalitarian and imperialist periods of Islamic history. Particularly, his view of 'Umar ibn al-Khattab as free from any associations with imperialism, hierarchy, or slavery seems a bit too rosy. For instance, he reads in an emancipatory light Umar's famous pronouncement that no Arab can be enslaved, without considering the potentially hierarchical or chauvinistic implications of such a pronouncement.

In an insightful section from Chapter 3, Freamon highlights Ahmad ibn Tulun's legacy in establishing military slavery in Egypt and "elaborat[ing] the variety of functions that slaves could play in Egyptian society" (211). This focus on Egyptian military slavery leads him into Chapter 4, where he presents his understanding of the "Mamluk/Ghulam phenomenon." Closely following the work of David Ayalon, Freamon argues that the heart of the Mamluk/Ghulam phenomenon is loyalty; that military slavery goes handin-hand with the use of eunuchs and concubines; and that military slavery is a "preeminently Islamic" institution (226). He controversially argues that the Mamluks were not dishonored persons, and in fact that "that slavery was destigmatized in the eyes of the populace because of the Mamluks" (228). However, he later acknowledges that the Mamluks were often viewed as "unruly, ill-mannered, and immoral" (291) by the native population of Egypt. It would be worth analyzing more deeply the relationship between the Mamluks' slave origins and their reputation for unruliness; it is also possible to read the Mamluks' patronage of Islamic scholarship and pious endowments as a compensation for the dishonor of their slave origins. In any case, there is room for more work on the honor/dishonor of military slaves (such as the recent articles by Koby Yousef).

Chapter 6 organizes all the previous historical material into a brief taxonomy of slavery, comprising the following categories: domestic servitude, military and naval slavery, concubinage, "gang" and plantation slavery, and "sultanic" slavery (which includes eunuchs). The ideas of loyalty, interdependency, and mutuality_ideas encapsulated by the phrase "mā malakat aymānukum"- - undergird these different categories. This taxonomy is a useful tool for understanding forms of slavery associated with the Islamic 
world, but historians will likely urge caution in applying to specific historical contexts. This is not so much a criticism of the typology, as a call for continuing interdisciplinary dialogue.

After setting this historical groundwork, chapters 7 through 9 turn to the failure of abolitionism and the continuing legacy of slavery in the contemporary Islamic world. While the British are often viewed as pushing a strongly abolitionist agenda, Chapter 7 focuses on British policies that allowed the continuance of slavery. Loopholes such as the India Exemption, as well as British protection of the Omani-Zanzibari slave trade, "did not and could not have led anyone to believe that the British were unequivocally in favor of abolition" (363). Chapter 8 continues with case studies of three nineteenth-century Muslim sovereigns (the Qajar Muhammad Shah, Egyptian Khedive Ismail, and Zanzibari Sultan Barghash). The chapter's final section on Zanzibar is particularly rich, with fantastic color photographs and reproductions of correspondences between Sultan Barghash and British politicians. Building on this history of failed abolitionism, Chapter 9 argues that slavery was never actually abolished in the Islamic world. He provides examples of continued slavery-including slavery in new guises such as the kafäla system-in Maurtania, Niger, and the Arabian peninsula. He blames these continued practices on a lack of "moral discourse and basic education on the problem of enslavement" in the Islamic world (463), where slavery is treated as a uniquely Western/American problem.

Finally, arguing strongly that this problem needs to be rectified, Chapter 10 shows how Islamic law can and should abolish slavery. Freamon calls on the global Muslim community (and scholars of Islam) to counter the claims of jihadi-salafi groups such as ISIS. The roadmap he provides for such work draws on Islamic notions of justice and freedom, interprets potentially problematic Quranic passages in anti-slavery ways, and invokes legal concepts of consensus and the common good. He warns that if Muslims fail to articulate an authentic Islamic law of abolition, it will signal Islamic law's failure as a viable legal system for the contemporary world.

While this final chapter speaks directly to a Muslim audience, the book will be of great interest to all scholars of Islamic law, Islamic history, global history, and slavery/abolition. Because it is so expansive, even scholars from these various fields are likely to experience some "information overload." Historians of specific contexts (particularly pre-modern contexts) will also find that the generalizations made in any work of synthesis necessarily erase some of the interesting nuances, debates, and puzzles of those specific contexts. Moreover, speaking as a specialist in early Islamic 
history, I found that many of the secondary works he uses are older classics in the field (such as works by Hodgson, Lapidus, Watt, and Popovic), rather than newer, more cutting edge, or revisionist scholarship. Though it is impressively comprehensive and erudite, this book is certainly not the end of the discussion on slavery in the Islamic world; rather, it is a fantastic introduction to the problem of slavery's legacy, an invitation to continued interdisciplinary conversation, and a compelling call for political activism.

Elizabeth Urban

Associate Professor of History West Chester University, West Chester, PA

doi: 10.35632/ajis.v37i3-4.1118 